\title{
Women's Participation in Tourism Activities: A Case Study of Baduy Tribe
}

\author{
Rina Fitriana 1,* (D) Dadan Sujana 2, (D) and Dino Gustaf Leonandri ${ }^{3}$ \\ 1 Department of Hospitality, Politeknik Sahid, 10220, Jakarta, Indonesia \\ 2 Department of History Education, STKIP Setiabudhi, 42314, Banten, Indonesia \\ ${ }^{3}$ Department of Hospitality, Sekolah Tinggi Pariwisata Trisakti, 12330, Jakarta, Indonesia \\ * Corresponding Author: rinafitriana@polteksahid.ac.id
}

ARTICLE INFO
$\begin{aligned} & \text { Publication Info: } \\ & \text { Research Article }\end{aligned}$
How to cite:
Fitriana, R., Sujana, D., E
Leonandri, D. G. (2020). Women's
Participation in Tourism
Activities: A Case Study of Baduy
Tribe. Society, 8(2), 640-649.

DOI: $10.33019 /$ society.v8i2.220

Copyright (C) 2020. Owned by Author(s), published by Society

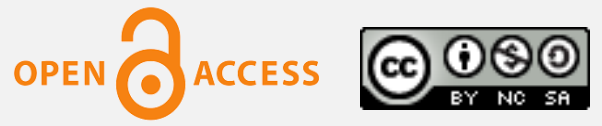

This is an open-access article.

\section{License: Attribution- \\ NonCommercial-ShareAlike (CC BY-NC-SA)}

Received: August 20, 2020;

Accepted: December 22, 2020;

Published: December 30, 2020;

\begin{abstract}
This research aims to analyze women's participation in tourism activities in the Outer Baduy tribe, according to the tourism components consisting of attraction, amenity, accessibility, and ancillary (supporting factors). This research uses a qualitative research method, in which data collected through interviews, observations, and documentation. This research involved 18 informants from several stakeholders, such as the tourism awareness group, handicraft producers, homestay and restaurant owners, government officers, and tourists who have visited the destination. Informants' selection uses a purposive sampling technique. According to the tourism components, the research results show women's participation in tourism activities in the Outer Baduy tribe, only two of four tourism components: attraction and amenity. In the attraction component, women possess more or less the same level of participation as men. However, in the amenity component, women may have a higher level of participation than men may. In the accessibility and ancillary (supporting factors) components, only men participation existed. The limited level of women's participation is rooted deep and taken for granted in their culture. The women themselves do not dispute inequality and disparity because they consider their role as women in the domestic sector and not in the public sector.
\end{abstract}

Keywords: Baduy Tribe; Culture; Gender; Tourism Components; Women's Participation

Copyright (C 2020. Owned by Author(s), published by Society. This is an open-access article under the CC-BY-NC-SA license. 


\section{Introduction}

The regency government of Lebak continues to explore the potential of tourism that will develop as the sources for Local Revenue to promote economic growth and boost the community's welfare. The local resources development to be a tourist destination is an alternative economic growth that relies on the agricultural sector. The Regent of Lebak, Octavia Jayabaya, stated that the local government, over the next five years, focuses on developing the tourism sector to improve the community's economic growth. The tourism sector development aims to reduce poverty and unemployment rates (Beritafakta. id, 2019). Several potentials of Lebak Regency are its natural resource and cultural specificity. Lebak is also famous for its Baduy tribe, a group of people living in a Kabuyutan, considered a sacred traditional Sundanese village. The people there call themselves Urang Kanekes, which means people from Kanekes.

Urang Kanekes inhabited and lived a simple life in South Banten's hinterland, precisely located in Kanekes Village, Leuwidamar Subdistrict, Lebak Regency, Banten Province, and are part of the Kendeng Mountains areas (900 MASL), which has an average temperature of $20^{\circ}$ Celsius. The Kanekes village area ranges from 5,101.85 hectares, consisting of 2,101.85 hectares of residential areas and an area of absolute protected forest (Taneuh Larangan) of 3,000 hectares. It is the largest rural area in Banten Province. According to the 2012 population census, the Outer Baduy community amounted to 9,826 inhabitants in 57 villages and 5 Babakans (new village).

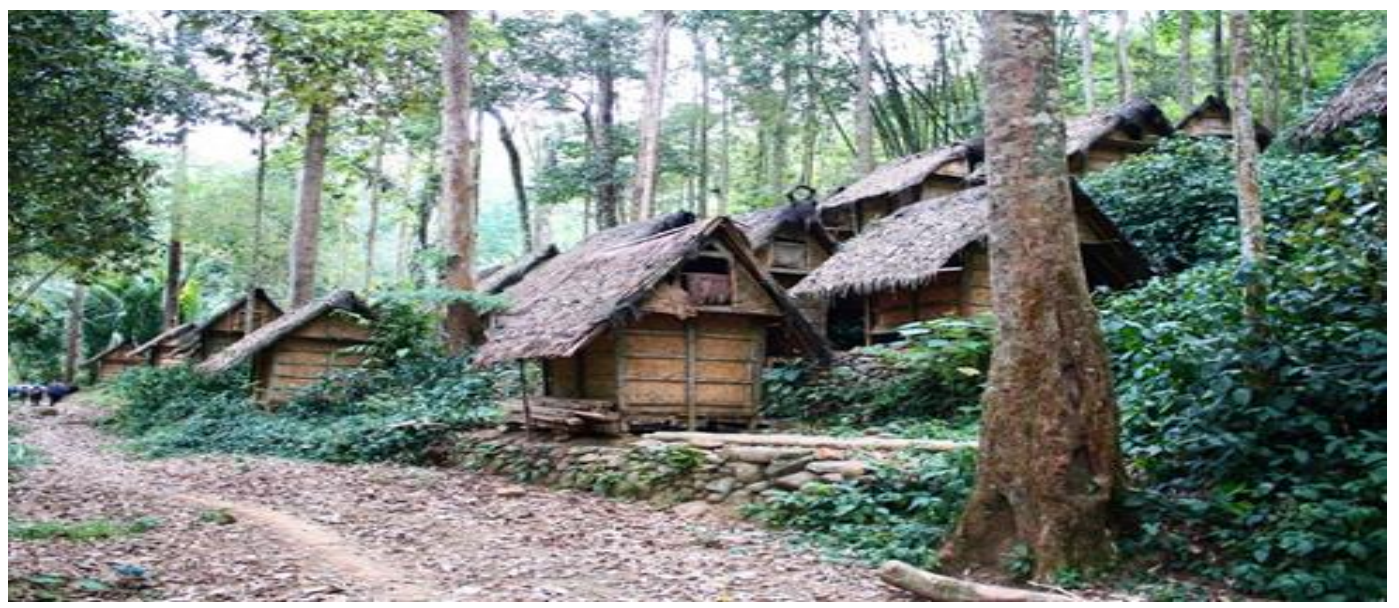

Figure 1. Baduy Village

Source: Personal Documentation (2019)

Their main livelihood is moving farmers. Rice planting in the ricefields (Ngahuma), considered a ritual of marriage between the Goddess of Rice named Nyi Pohaci Sang Hyang Asri with the earth. Urang Kanekes also believe they are the origin of life on earth and consider their territory as the core of the earth or the universe's core to maintain the world's core (Jagad). The preserved and prosperous core of the Jagad will influence the entire universe's welfare and prosperity, including the people living in it.

To maintain the purity of the core of Jagad, Urang Kanekes are obliged to preserve their customs according to their ancestors' teaching (Karuhun). Some of their teaching principles are well-known among Sundanese, such as "lojor teu meunang dipotong, pondok teu meunang disambungan" (what is long should not be cut, what is short should not be extended). Furthermore, "larang teu meunang dirempak, buyut teu meunang dirobah" (prohibition should not be violated, taboo should not be changed). Those living in the Inner Baduy, who still rely on

Copyright (C) 2020. Owned by Author(s), published by Society. This is an open-access article under the CC-BY-NC-SA license. 
their customs for all sides of their life and altogether reject modernization, mainly apply these strict customary rules.

Isolated residential, the attitude of life upholding the Karuhun culture, and the rejection of modernization have encouraged many researchers interested in the history of this tribe. There are three opinions on the origin of Urang Kanekes:

1) They were initially an escape from Pakuan Pajajaran, who rescued themselves from the invasion of Muslim alliances from Banten, Cirebon, and Demak.

2) They were displaced and expanding the Sultanate's territory, initially embraced Hinduism, and lived in Mount Pulosari.

3) The opinion of Urang Kanekes themselves who believe that their ancestors were already in the area.

Danasasmita \& Djatisunda (1986) concluded that Baduy village built as a mandala (sacred area), which was determined by the king, and the inhabitants were obliged to maintain the shrine of Sunda Wiwitan (ancestral place of ancestors). Considering Baduy tribe's strong customs, tourism activities in the region must have a significant challenge.

Demartoto (2009) stated that in addition to the problems in the destination management and the lack of community involvement in it, women's participation also determines the development of the prosperous tourist village. Indirectly, it proves that women's roles also determine the success of community-based tourism. It is normal because the composition of Indonesia's population has more women than men, so whether we like it or not, women's role must be a determining factor in developing a prosperous community-based tourist village. Women as an intact individual and a part of the community have the equal right and potential to participate in community-based tourism activities. Expectedly, women's participation can reduce gender inequality in development, where women do not have a proportional representation to voice their interests.

Gender problems usually arise due to the lack of women's awareness as independent individuals. It leads to the enormous amounts of women themselves seeing their problems were not subjects to particular attention. Sri Lestari (2007), as cited in Siswanto (2009), argues that the lack of understanding of this issue perhaps resulted from traditional values regarding women's limited role in public affairs, as it is common in a patriarchal society. Women's opportunities to work outdoors and have their jobs, considered against the tradition. It also gives them lesser access and unequal opportunity to pursue formal education.

Improvement of women's equality and empowerment has been the agenda in the Millennium Development Goals (MDGs) proclaimed by the UN in 2000, based on a joint agreement of 189 United Nations Member States including Indonesia (Handayani, 2006). UNWTO (2011), as cited in Pritchard (2014), describes some of the common facts about women in tourism, and among those facts are the facts that women workers in this field are more in numbers than men workers. However, women's wages are smaller than men's are. Not many women hold high positions in tourism professionals' work, and the tourism business owned women own more than those by men-owned. Early observations conducted in the Outer Baduy tribe's tourist village showed that women participated in several tourism activities components. With the increasing number of women involved, it is necessary to identify their roles to maximize their potential.

This research aims to examine the role of women in tourism activities. It is needed because many studies have shown that the destination, in which the women play a significant role, usually has a better condition and may progress sooner.

Copyright (C) 2020. Owned by Author(s), published by Society. This is an open-access article under the CC-BY-NC-SA license. https://doi.org/10.33019/society.v8i2.220

642 


\section{Literature Review}

Sofiani (2009) stated that women's participation is an active role of women in the decisionmaking process, execution of decisions, and obtaining the outcome or risk of overall activities related to the development efforts undertaken. According to Raharjana (2012), the awareness of the whole village community would make it easier to build a tourism village based on the principle of locality, where the tourism village is coming from the community and allocated to the prosperity of the community by using the natural and human resources of the village.

Unfortunately, there are still many cases in which women do not optimize their potential due to stereotypes and gender bias within the community. According to Dermatoto (2009), low women's involvement in tourism management due to the lack of knowledge and experience and the lack of facilities and capitalization. Besides, the government's gender bias shows the government's failure as a facilitator. However, Umiarti \& Sukana (2014), in their research in the Talumben Bali, many women were employed as porters, namely the lifters of diving equipment. Although still limited in number, women's participation as diving equipment carriers is an exciting finding because men usually do this type of work. It proves that job restriction could vanish when society becomes more opened and modern. Although women still encounter challenges in the tourism sector due to gender bias, Ghodsee (2005) believes that tourism development and flexibility will allow women to fulfill their best potential in social, economic, and political terms. UNWTO (2011), as cited in Pritchard (2014), also convinced that the tourism sector is still more hospitable to women than in many other sectors.

Mulyadi \& Andri (2016) said that tourism is an activity, service, and product of the tourism industry that creates a tourists' travel experience. According to Yoeti (2010), tourism is a journey of going out for leisure and merely becoming a consumer in the destination. Furthermore, Cooper \& Wahab (2001) stated that tourism has three elements, namely human (traveler), places (destination), and time (length for both travel and stay).

The government projected Indonesian tourism in 2019 to be the second-largest foreign exchange producer after palm oil. Bryden (1978) believes that the tourism sector is very suitable for countries with a large population because it can employ the workforce and improve society's welfare within a relatively short time. Faulkner (1998) argues that natural beauty, cultural richness, and human resources can be tourist attractions that will bring foreign exchange if these factors are synergized and presented using proper packaging.

Cooper (1993), as cited in Suwena (2010), stated that a tourism destination must have four tourism components to meet the needs of tourists, which consist of:

1) Attractions

Unique components that attract tourists to visit and consist of three things, which consist of:

a. Natural resources, such as waterfalls, hills, lakes, and others;

b. Cultural attractions, consisting of dances, music, and songs, and many other types of art;

c. Human-made attractions, such as photo spots, tree houses, and others.

\section{2) Amenity}

Some facilities needed by tourists while staying in the destination such as lodging, restaurant, travel agency, currency exchange, bank, and others. The infrastructure such as water, electricity, landfills, and others.

\section{3) Accessibility}

Accessibility is the most crucial thing in tourism activity. It includes all kinds of public transportation or transportation services to reach the destinations. This access also includes 
transferability, namely the ease to move from one area to another. If accessibility supports such as airports, ports, terminals, public roads, and others are still lacking, it will be difficult for a tourism destination to develop.

\section{4) Ancillary (supporting factors)}

Additional services provided by the government in tourist destinations for tourists and people working in the tourism sector, including marketing, tourist information centers, tourism organizations, and others.

\section{Research Methodology}

This research uses a case study research technique, a qualitative research approach conducted by investigating a case or several cases from time to time through a detailed collection of data involving many sources of information and reports on case descriptions of these and case-based themes (Creswell \& Poth, 2017). The technique of data collection in this research is interviews, observations, and documentation studies.

This research involved 18 informants from several stakeholders, such as the Tourism Awareness Group (Pokdarwis), handicraft producers, homestay and restaurant owners, government officers, and tourists who have visited the destination. Informants' selection uses a purposive sampling technique. Data analysis has three phases in this research: data reduction, data presentation, and withdrawal of conclusions or verification. Data reduction involves sorting field data by focusing on essential things and searching for themes and patterns (Sugiyono, 2011). The presentation of data is a collection of organized information that can withdraw and take action. Meanwhile, verification is the process of looking for patterns, regularity, explanation, and cause of the consequences that were previously loose into the cone (Syahrum \& Salim, 2014).

\section{Results and Discussion}

\subsection{Attraction}

Some famous arts of Baduy tribe are Angklung Buhun, Koromongan, Kacapi, Rendo, and the new art of Celempungan. At first, the Angklung art was played traditionally by the people of Baduy. In 1938, Daeng Soetigna was able to play European songs with Angklung and continued by his student named Udjo Ngalagena. Today, "new" Angklung famous and got recognition from UNESCO. Therefore, the naming of Angklung for Baduy community, which was initially named Angklung, got an additional word becomes Angklung Buhun, which means "Angklung the beginning/old" (Johari \& Sujana, 2014).

In the traditional Angklung Buhun, the players must be men. Twelve players consist of nine players of Angklung and three players of Bedug. In Baduy community, Angklung only played in a specific moment, usually once in a year, in the seventh month of Baduy community calendar. Precisely, at the ceremony of Ngaseuk, namely the wedding ceremony of Nyi Pohaci Sanghyang Asri (Dewi Sri/Dewi Padi) with the Earth or the Land. Angklung music performed as Pangrérémo (matchmaking), in the area of Panamping music Angklung followed by singing (vocals) voiced by Jaro Angklung and performed while Ngalagé (dancing). Because of its sacredness, only men can play Angklung Buhun art.

Koromongan originates from the word Kromong or Keromong, which means the gamelan, which made of bronze or iron. The players are usually 10-12, and each is holding their instruments, plus two singers (usually women). During playing the instruments and singing, it is normal for players to be so fun and relaxed while drinking coffee or bandrek and eating 
rangginang.

Other attractions in the Outer Baduy tribe are ceremonies. Not all of these ceremonies opened to tourists. However, among those ceremonies, there is one well-known ceremony that has been listed in an annual agenda of the Banten provincial government and included in the Calendar of Event (CoE) Wonderful Indonesia, namely Seba Baduy ceremony. According to Danasasmita \& Djatisunda (1986, p. 8), the ceremony aims to fulfill one of six life tasks, ngasuh ratu ngajak menak (nurturing rulers and authorities).

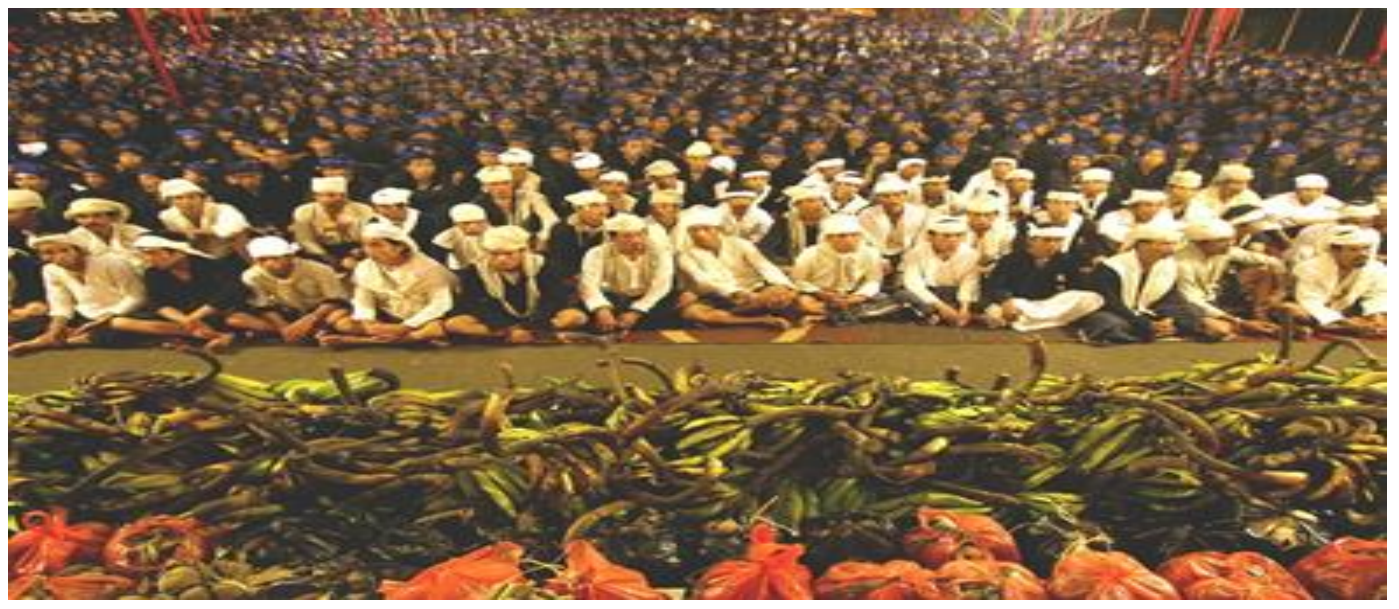

Figure 2. Seba Baduy

Source: Personal Documentation (2019)

Seba Baduy ceremony is a form of gratitude showed by Urang Kanekes over the abundance of harvest. This gratitude was expressed by sharing with the community outside the area, including visiting Ibu Gede and Bapak Gede, namely the governor and regent/mayor who lead in Banten province. Baduy tribe elders believe that this ceremony is an inheritance of Kokolot (ancestors) and must hold annually. On this occasion, the representatives of Urang Kanekes, all consist of men; also convey messages and request to the government in their development program must in line with the efforts to preserve nature.

To reach the Banten Province building office, Baduy community must walk for tens of kilometers. Before the year 2014, this building previously for the Resident of Banten. In 1828 established as Wooning Residentie Bantam (residential Resident of Banten) (Ali \& Darmayanti, 2014). It could be that the long-distance is one of the reasons why the community representatives involved in this ceremony is all men. It also proves that women in Baduy community were never formally involved in any customary governance structure. It is in line with Muttaqien (2019), which stated that Baduy women's participation in Sunda Wiwitan is only in the domestic sector and less in the public sector, including in traditional and religious ceremonies.

In addition to the art, the biggest attraction of Outer Baduy is their way of life, buildings, and environment. In daily life, such as planting rice, both men and women together work in the fields. Interestingly, planting rice is the tradition of cooperation between husband and wife, where the husband prepare holes and the wife put the seeds. In daily farming activities, men and women together work in their fields and gardens. The women also involve in rice mashing using a traditional tool called Lesung. The sound generated by Lesung can be a piece of beautiful music when combined with the sound of Angklung played by men.

Therefore, it can be concluded that in the attraction component, women's participation showed in their involvement in various kinds of Baduy art and daily life that is still considered

Copyright (C 2020. Owned by Author(s), published by Society. This is an open-access article under the CC-BY-NC-SA license. https://doi.org/10.33019/society.v8i2.220

645 
the biggest attraction for tourists staying in the village. However, like it or not, women's participation in this component is still limited by taboos or restrictions in the tribe.

\subsection{Amenity}

Women work in several places related to the amenity component, such as restaurants, homestay, grocery stall, and gift/souvenir shop. Women mostly do the work in this tourism business. Women run the restaurant, and they are the ones who run all operational phases, from cooking to serving the guests, as well as running managerial tasks such as calculating profit or loss. The same thing in grocery stalls and gift/souvenir shops, although men are participating in waiting for the stall/shop and serving buyers. The goods sold in the souvenir shop also produced through women's participation in its production and packaging, such as found in palm sugar production, even some of those souvenirs production process entirely done by women, such as Batik Baduy woven fabric.

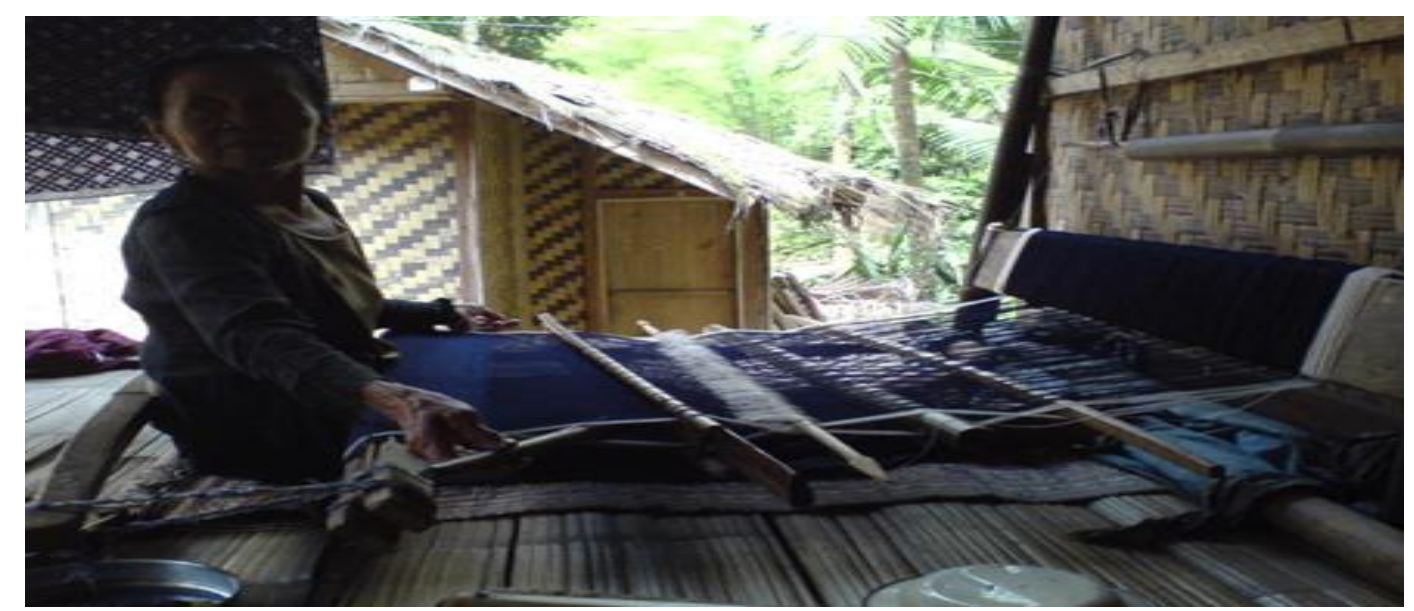

Figure 3. Baduy woman weaving cloth

Source: Personal Documentation (2019)

Baduy men have their part in producing certain goods, such as honey and palm sugar. The famous honey from Baduy is the wild honey obtained by hunting the beehive in the woods. This work is considered too heavy and risky, so it is only the men working on it. Similarly, the palm farmer tapping the water of nira/kawung as the main ingredient in making palm sugar. It is done only by men because it requires intense physical and courage to climb into the palm tree and tap the water of nira/kawung, which is also considered too risky for women.

Interesting findings during the interview about homestay revealed. Some sources reveal no homestay in Baduy area, both outside and inside, because they are unwilling to use their house as a homestay. Guests who visit Baduy area can stay at anyone's house free of charge. As for a visit, tourists can freely participate in their daily activities, and again without any charge. The people consider that tourists are the guests who have to be treated and served well. Therefore, Urang Kanekes will never refuse tourists who intend to spend the night in their house, and they do so without asking for money.

At home, women are responsible for all tasks, from housekeeping to serving the guests. Their daily task, such as harvesting vegetables from the garden, processing it with traditional equipment such as a furnace, and serving it traditionally, is considered a tourist attraction. Women also accustomed to doing side works like being weaving cloth or producing palm sugar at home. The tourists can engage in the production to add their insight and experience during

Copyright (C 2020. Owned by Author(s), published by Society. This is an open-access article under the CC-BY-NC-SA license. https://doi.org/10.33019/society.v8i2.220 
their stay. Women made Baduy woven fabrics and usually sold to tourists at a reasonably affordable price.

\subsection{Accessibility}

All jobs related to accessibility in tourism, such as drivers, taxi bike drivers, and others, are done by outsiders. The work of people in Outer Baduy was limited to farming and trading. The only work they do relating to accessibility is to work as a porter for tourists who want to explore the place. Men's involvement in this type of work because it is considered heavy physical work. Of course, this is different from Umiarti \& Sukana (2014), in their research in the Talumben Bali, which found that women are involved in physical work like porters.

The difference happens because Balinese are more open in culture, so there is less disparity between men and women in terms of the opportunity to work. Another possibility is a decisive economic driving factor that forces Balinese women to get off to work fulfilling life necessities. In conclusion, In conclusion, there is no women's participation in this component, but men's participation is limited.

\subsection{Ancillary (Supporting Factors)}

Institution as one supporting tourism components is necessary to ensure the management of a well-maintained destination. Urang Kanekes living in outer Baduy has formed the Pokdarwis (Tourism Awareness Group) that serves as a tourism initiator in the area. All members of the Pokdarwis are male. No female members in the Pokdarwis. The women are more pleased in doing domestic activities and feel that such public and formal organization is the realm of men, so they refuse to participate. Men compose all the rules regarding the visit, and other rules. Women are not involved in the village governance structure.

Through interviews, women entrust their interest to men because they realize their customs and traditions favor them. In the rules of marriage, Urang Kanekes are not allowed to conduct polygamy and divorce. Such rules make the women personally protected, and contended (Muttaqien, 2019).

There is no women's participation in the ancillary (supporting factors) component. It is in line with Maharani (2009) stated that in Sunda Wiwitan, women are preparing everything behind the scenes. However, they do not take place on stage due to cultural and religious restrictions. However, the women accept such restrictions and even reject them when given a more extensive social role. It is presumably arising from the strong tradition and custom that bind the life of Urang Kanekes.

\section{Conclusion}

In conclusion, through the descriptive qualitative research conducted, women participate in two out of four tourism components: attraction and amenity components. In the attraction component, men's and women's participation level is equal, while in the amenity, women's participation is higher than men's participation. Furthermore, in the accessibility component, there is limited men's participation, and there is no women's participation in this component. In the ancillary (supporting factors) component, men's participation is high, while there is no women's participation in this component. The limited women's participation in some tourism components resulted from the customs or traditions. However, they never considered it as a significant problem, even by the women themselves. Due to the strong tradition, the women were accustomed to their domestic roles, so they refused to participate in more public roles. Another reason that could encourage women to accept this condition is the living that is 
considered safe, contented, and prosperous. Thus making them quite satisfied with their domestic roles and not demanding to go into the public roles because they believe that all women's interests have been represented and protected by their customs and traditions, and men have fulfilled women's needs.

\section{Acknowledgment}

The authors are grateful to express gratitude to those who have had the pleasure to cooperate during this study.

\section{Declaration of Conflicting Interests}

The authors have declared no potential conflicts of interest concerning the study, authorship, and/or publication of this article.

\section{References}

Ali, M., \& Darmayanti, T. (2014). Sejarah Bangunan Pendopo Gubernur Banten. Serang, Indonesia: Dinas Kebudayaan dan Pariwisata Provinsi Banten.

Beritafakta.id. (2019, September 2). Bupati Lebak Fokus Bangun Sektor Pariwisata. Berita Fakta. https:/ / beritafakta.id/bupati-lebak-fokus-bangun-sektor-pariwisata/

Bryden, J. M. (1978). Tourism and development: A case study of the Commonwealth Caribbean. Cambridge: Cambridge University Press.

Cooper, C., \& Wahab, S. (Eds.). (2001). Tourism in the Age of Globalisation (1st ed.). London, UK: Routledge.

Creswell, J. W., \& Poth, C. N. (2017). Qualitative Inquiry and Research Design: Choosing Among Five Approaches (4th ed.). Thousand Oaks, Canada: SAGE Publications.

Danasasmita, S., \& Djatisunda, A. (1986). Kehidupan masyarakat Kanekes. Bandung, Indonesia: Bagian Proyek Penelitian dan Pengkajian Kebudayaan Sunda (Sundanologi), Direktorat Jendral Kebudayaan, Departemen Pendidikan dan Kebudayaan.

Demartoto, A. (2009). Pembangunan Pariwisata Berbasis Masyarakat. Surakarta: Sebelas Maret University Press.

Faulkner, B. (1998). Tourism Development Options In Indonesia and The Case Of AgroTourism in Central Java. In B. Faulkner, E. Laws, \& R. Moscardo (Eds.), Embracing and Managing Change in Tourism: International Case (1st ed., pp. 202-221). London, United Kingdom: Routledge.

Ghodsee, K. R. (2005). The Red Riviera: Gender, Tourism, and Postsocialism on the Black Sea. Durham, USA: Duke University Press.

Handayani, T. S. (2006). Konsep dan Teknik Penelitian Gender. Malang, Indonesia: Universitas Muhammadiyah Malang Press.

Johari, D., \& Sujana, D. (2014). Identifikasi Seni Pertunjukan Tradisional Provinsi Banten. Serang, Indonesia: Dinas Kebudayaan dan Pariwisata Provinsi Banten.

Maharani, S. D. (2009). Perempuan dalam kearifan lokal Suku Baduy. Jurnal Filsafat, 19(3), 199213. Retrieved from https://journal.ugm.ac.id/wisdom/article/view/3435

Muljadi, A. J., \& Andri, W. (2016). Kepariwisataan dan Perjalanan (5th ed.). Jakarta, Indonesia: Rajawali Pers.

Muttaqien, Z. (2019). Peran Perempuan dalam Tradisi Sunda Wiwitan. Khazanah Theologia, 1(1), 23-39. https:/ / doi.org/10.15575/kt.v1i1.7123

Copyright (C 2020. Owned by Author(s), published by Society. This is an open-access article under the CC-BY-NC-SA license. 
Pritchard, A. (2014). Gender and Feminist Perspectives in Tourism Research. In The Wiley Blackwell Companion to Tourism (pp. 314-324). John Wiley \& Sons, Ltd. https:// doi.org/10.1002/9781118474648.ch25

Raharjana, D. T. (2012). Membangun pariwisata bersama rakyat: Kajian partisipasi lokal dalam membangun Desa wisata di dieng plateau. Kawistara: Jurnal Ilmiah Sosial dan Humaniora, 2(3), 225-238. Retrieved from https://journal.ugm.ac.id/kawistara/article/view/3935

Siswanto, V. (2009). Studi Peran Perempuan Dalam Pengembangan Usaha Kecil Menengah Melalui Teknologi Informasi Di Kota Pekalongan. Dinamika Informatika: Jurnal Ilmiah Teknologi Informasi, 1(1), 70-77. Retrieved https:// www.unisbank.ac.id/ojs/index.php/fti2/article/view/267

Sofiani, T. (2009). Membuka Ruang Partisipasi Perempuan Dalam Pembangunan. MUWAZAH: Jurnal Kajian Gender, 1(1), 63-72. Retrieved from http://ejournal.iainpekalongan.ac.id/index.php/Muwazah/article/view/280

Sugiyono. (2011). Metode Penelitian Kuantitatif Kualitatif dan $R \&$ \& . Bandung, Indonesia: Alfabeta.

Suwena, I. K. (2010). Pengetahuan Dasar Ilmu Pariwisata (1st ed.). Denpasar, Indonesia: Udayana University Press.

Syahrum, \& Salim. (2014). Metode Penelitian Kuantitatif. Bandung, Indonesia: Citapustaka Media.

Umiarti, A. T., \& Sukana, M. (2014). Partisipasi Perempuan dalam Aktivitas Wisata Bahari (Studi Kasus Objek Wisata dan Daya Tarik Pantai Talumben Bali). Prosiding Seminar Nasional tentang Hasil-Hasil Penelitian dan Pengabdian pada Masyarakat Sebagai Aktualisasi Tri Dharma Perguruan Tinggi, 215-221. Bali, Indonesia: UNMAS Press.

Yoeti, O. A. (2010). Dasar-Dasar Pengertian Hospitality dan Pariwisata (1st ed.). Bandung, Indonesia: Alumni.

\section{About the Authors}

1. Rina Fitriana, obtained her Magister degree in Management from Universitas Mercu Buana, Indonesia, in 2017. The author is an Assistant Professor at the Department of Hospitality, Politeknik Sahid, Indonesia, and a Master Trainer at the Ministry of Tourism and Creative Economy of the Republic of Indonesia.

E-Mail: rinafitriana@polteksahid.ac.id

2. Dadan Sujana, obtained his Magister degree in History Education from Universitas Pendidikan Indonesia, in 2013. The author is a lecturer at the Department of History Education, STKIP Setiabudhi and the Founder of Banten Heritage.

E-Mail: sujana@stkipsetiabudhi.ac.id

3. Dino Gustaf Leonandri, obtained his Doctoral degree in Management Science from Universitas Pasundan, in 2020. The author is an Assistant Professor at the Department of Hospitality, Sekolah Tinggi Pariwisata Trisakti, Indonesia, and a General Manager of Fairfield by Marriot Belitung.

E-Mail: dinoleonandri@stptrisakti.ac.id

Copyright (C) 2020. Owned by Author(s), published by Society. This is an open-access article under the CC-BY-NC-SA license. https://doi.org/10.33019/society.v8i2.220 